\title{
予備電離自己始動型放電電極
}

\author{
正員堤 泰 行 (茨城 大) \\ 正員沼田義 道 (日立製作所) \\ 非会員 長 江 弘 允 (日立製作所) \\ 非会員 弓 野 真 孝 (日立オートモーティブエンジニアリング)
}

\section{Pre-Ionized Self-Triggering Discharge Electrode}

Yasuyuki Tsutsumi, Member (Ibaraki University), Yoshimichi Numata, Member, Hiromitsu Nagae, Non-member (Hitachi Ltd.), Mititaka Yumino, Non-member (Hitachi Automotive Engineering)

A strange and peculiar phenomenon was found in which pulse discharge inception voltage of a small gap decreased considerably by using an electrode with a dielectric. The dielectric was contact with an edge of the electrode which position was far isolated from the gap.

The discharge inception voltage decreased with increasing permittivity of the dielectric and with reducing distance between the discharge position and the electrode edge with the dielectric. Residual charge on the dielectric was observed after application of high pulse voltage enough to discharge the gap. Potential of the dielectric was adjusted by resistive connection between conductive paint on the dielectric surface and the electrode, and was shown to influence the discharge inception voltage of the gap. A light shield between the electrode edge with the dielectric and the gap also influenced the discharge inception voltage of the gap definitely.

These phenomena can be explained by pre-ionized self-triggering discharge. A peculiar point is that this electrode has no adjacent third electrode for triggering the discharge. The discharge is concluded to be triggered by UV ray from pre-ionization at a far isolated edge of its own electrode, stress of which is enhanced by adding a dielectric.

キーワード：放電, 予備電離, 始動, トリガ, 点火, 自動車, 電波雑音

\section{1.はじめに}

通信システムの普及・多様化に伴い，機器から発生する 電波雑音を抑制することが強く求められている。

自動車点火系用ディストリビュータでは，火花放電から 出る電波雑音を抑制することが必要であり，このためディ ストリビュータギャップの放電電圧を低減することが有効 であることは古くから知られている(1)。放電電压を低隇す るため, 金属先端を剣山やようにした電極, 金属表面にセ ラミックスを溶射した電極，金属と誘電体を張り合わせた 笔極，あるいは抵抗性セラミックスを電極としたものな ど, 種々の電極が考案され，その一部は実用されてき た(2)(3)。誘電体を用いる電極で放電電圧が低くなる理由 は, 誘電体の誘電率や誘電体表面の電荷により䉓極表面の 電界が強まるためと考えられている(3)。実用されている電 極は，嚴しい耐久試験に耐えたものではあるが，放電によ
つて電極表面が影響を受けるという宿命をもっており，希 薄燃焼のための点火エネルギーの増強や製品の耐久性レ心゙ ルをいっそう向上したいなどの要求に応えるため, 更なる 研究・改善が必要と考えられる。

本報告は,ディストリビュー夕用電極の放電に関する研 究中, 著者の一人が偶然にも, 放電部から離れた電極端に 誘電体を配置することで放電電圧が大幅に低下するという 奇妙な現象を発見し，その原因究明のために行った研究の 結果をまとめたものである。

研究の結果, この現象は従来のディストリビュータ用電 極とは放電電圧低減の原理が異なり, 電極端部の予借電離 によって主放電部の放電が始動するという予備電離自己始 動型放電であることが判明した。

予備電離による紫外光によって主放電を始動させる技衡 は古くから知られているが，これらはすべて始動用の第 3 電極を備えている。例えば，エキシマレーザ用予備電離型 
放電電極を例にとると，金網電極の裏側に誘電体を介して 第 3 電極を配置し，金網電極の裹側で発生した予備電離に よって表側の主放電を始動させる方式が用いられてい る(4)。本報告の放電電極には，予備電離用の第 3 電極はな く, 誘電体によって自らの電極の電極端電界を高め予備電 離を発生させる方式である。始動用第 3 電極や始動回路の 配線もなく一つの電極に高電圧パルスを加えるだけで始動 用予備電離と主放電を起こすため, 従来知られている電極 と区別して予備電離自己始動型放電電極と呼ぶことにし た。これまで，このような電極について報告された例はな 裙

高電圧の近くに予備電離用第 3 電極を配置する必要がな いため，ディストリビュータのように，回転部に高電圧， 静止部に低電圧というように，高低圧回路が分離している 構造の場合にも，適用することが容易である。

本方式の放電電極は, 予供電離発生部と主放電部が離れ ているため, 主放電によって予備電離発生部を劣化させる 心配はほとんどない。このため, 従来のディストリビュー 夕用電極に比べ耐久性の面で画期的な改善が図れるものと 期待される。

\section{2. 実験方法}

〈2・1〉電極構成＼cjkstart実験に用いた電極構成を図 1 に示 す。(a)図は, 放電電圧低滅のための対策がなされていな い基準とした電極構成であり，負の高電圧パルスが印加さ

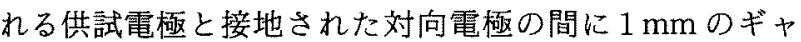
ップを設けた構造となっている。この電極と周囲の接地金 属との距離は $10 \mathrm{~cm}$ である。(b)〜 (d)図は電極部のみ 記述しているが，(a )図と同様周囲の接地金属との距離は $10 \mathrm{~cm}$ である。ディストリビュー夕の放電ギャップの長さ

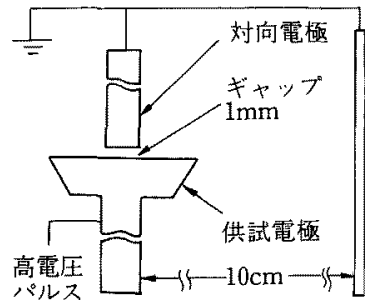

(a) 基準電極

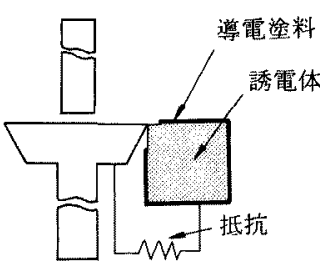

(c) 誘電体八の抵抗搂続

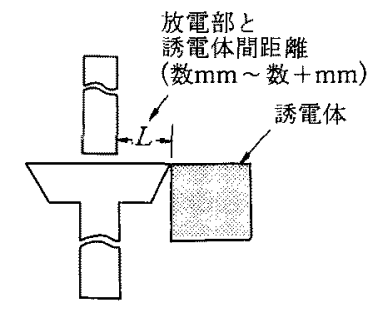

（b）誘電体付電栖

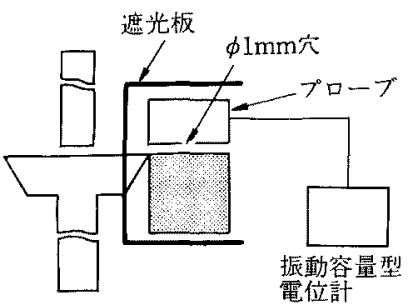

（d）誘電体電位の測定
図 1 電極構成

Fig. 1. Configuration of electrodes.
は通常 $1 \mathrm{~mm}$ 程度であるため, 従来から $1 \mathrm{~mm}$ ギャップ の電極構成でディストリビュータ用電極の評価が行われて いる(2)。1 mm ギャップの放電電圧を下げるのが目的であ るから，ディストリビュータ用電極の評価では， $1 \mathrm{~mm} キ ゙$ ヤップであ机ばどのような電極構成，電極材料を用いて実 験してもよい。供試電極は，厚さ $1.5 \mathrm{~mm}$ の板を図のよ うな構造に切り出したもので材質は黄銅である。誘電体と 接触することになる電極端は，30の角度でカットされた 形状となっている。この形状を用いているのは, 本研究で 述べる現象を偶然にもこの形状の電極を用いた実験で発見 したためである。対向電極は， $4 \mathrm{~mm}$ 角のアルミニウム角 棒で，すべての実験で同じものを使用した。

(b)図は，(a)図の供試電極の端に誘電体を配置した電 極構成である。誘電体はテフロン台の上にのせて図のよう に配置してあり，供試電極の電極端に接している以外は， 電気的には浮いた状態になっている。放電部と誘電体間の 距離 $L$ を変える実験では， $L$ が異なる供試電極を作成し 実験に用いた。 $L$ は, 数 $\mathrm{mm}$ 数十 $\mathrm{mm}$ である。この図 からもわかるように, 誘電体は放電が発生するギャップか ら離れた位置に配置されている。離れた位置に配置した誘 電体によってギャップの放電電圧が大幅に低下するという のが特異な点であり，その原因究明を行うことが本研究の 目的である。

(c)図は，誘電体表面のうち金属と接する点の周囲 2 $\mathrm{mm}$ 以内を除き，6面すべて導電塗料で被覆し，導電塗 料と金属部を抵抗を介して接続した構成を示す。この構成 は，金属と誘電体との間の電位差を変化させる実験で使用 した。

(d)図は, 誘電体の電位を振動容量型電位計を用いて湘 定する場合の配置を示す。図に示すように，誘電体中央か ら $2 \mathrm{~mm}$ 離れた位置に測定用プローブを配置し, プロー ブ中央の $\phi 1 \mathrm{~mm}$ の穴が測定部となっている。この振動容 量型電位計の時間応答性は $2.5 \mathrm{~ms}$ である。この構成は, 電極に高電圧パルスを 1 発印加した後の誘電体電位を測定 する実験で使用した。

またこの図には，誘電体と接する電極端部で発生した予 備電離の光が主放電部に届かないよう遮光板を設ける実験 での遮光板の配置も示している。遮光板は, 厚さ $1 \mathrm{~mm}$ のベークライト板を使用し，遮光板と供試電極との接合部 は常温硬化エポキシ樹脂で肉盛り接着した。

〈2・2〉誘電体の種類実験に用いた誘電体の種類を 表 1 に示す。放電電圧低減効果が大きい比誘電率 13 のフ エライトを標準試料として各種の実験を行った。

〈2・3〉高電圧回路波頭長を変える実験以外は，す ベて図 2 に示す高電圧発生回路を用いて実験した。これ は，コイルの一次回路の電流をトランジスタでオン・オフ することにより，二次回路に高電圧を発生するものであ る。高電圧測定のために，供試電極に直接高電圧プローブ (テクトロニクス社製 $\mathrm{P} 6016$, 静電容量 $3 \mathrm{pF}$, 分圧比 1 / 1,000）を接続している。放電電圧は高電圧プローブに接 
表 1 供試誘電体の種類

Table 1. Classification of tested dielctrics.

\begin{tabular}{c|l|r|c}
\hline No & \multicolumn{1}{|c|}{ 材料名 } & 比誘電率 & 体櫝抵抗率 $(\Omega \cdot \mathrm{m})$ \\
\hline 1 & テフロン & 2.3 & $1 \times 10^{15}$ \\
\hline 2 & シリコーン樹脂含浸ガラス䄉維 & 4.2 & $2.5 \times 10^{13}$ \\
\hline 3 & アルミナ & 5.6 & $5 \times 10^{9}$ \\
& & $\sim 11.2$ & $\sim 1.6 \times 10^{12}$ \\
\hline \multirow{2}{*}{4} & $\mathrm{Mg}-\mathrm{Mn}-\mathrm{Zn}$ 采フェライト & 12 & $4.8 \times 10^{7}$ \\
& & $\sim 13$ & $\sim 7.7 \times 10^{9}$ \\
\hline \multirow{2}{*}{5} & チタン酸化物系セラミックス & 28 & $1.3 \times 10^{9}$ \\
& & $\sim 107$ & $\sim 2.5 \times 10^{12}$ \\
\hline
\end{tabular}

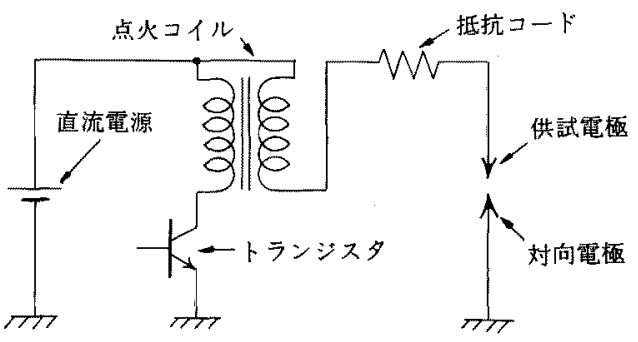

図 2 高電圧発生回路

Fig. 2. High voltage generating circuit.
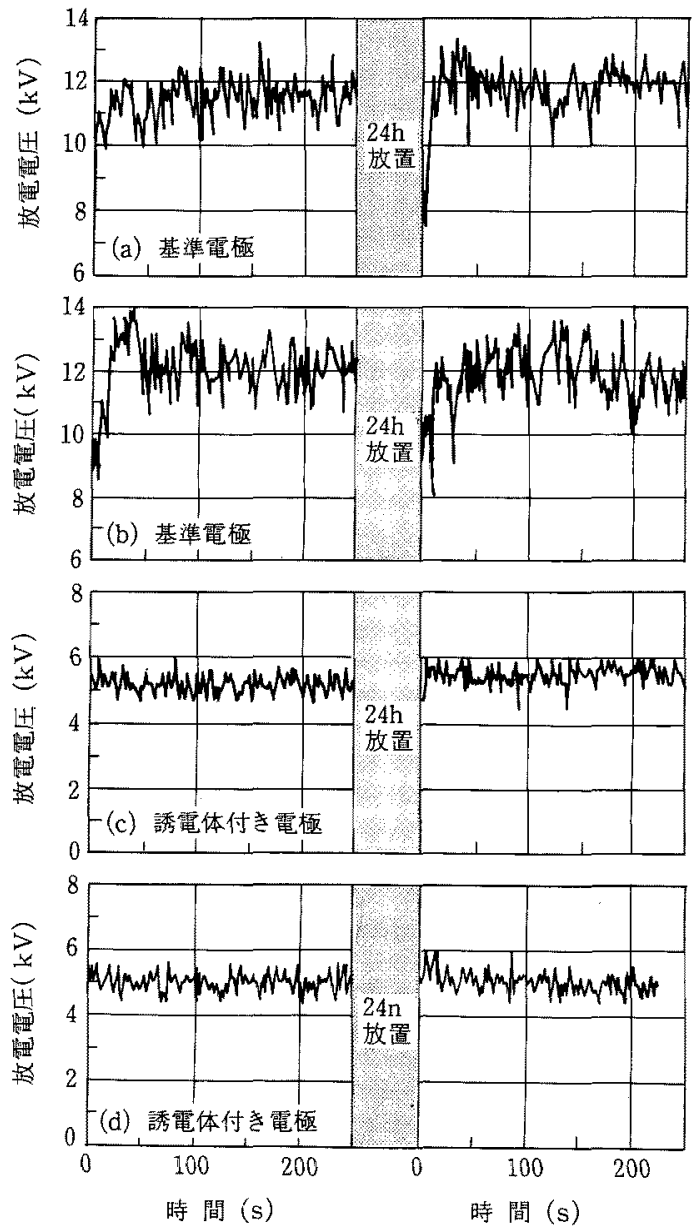

図 3 放電電圧の経時変化

Fig. 3. Discharge voltage histories.
続したオシロスコープの画面の波形で，電圧が放電によっ て急低下する直前の波形から求めた。基準として用いた高 電圧パルスの波形は, $90 \mu \mathrm{s}$ を半周期とする正弦波の半波 である。パルス頻度は，4 気筒， 1,500 回転/分のエンジン を想定し 50 パルス/秒を基準とした。

放電電圧は，図 3 に示すように，同一電極でも時間的に 変動し，ばらつきが大きい。このため, 図 4 以後の放電電 圧の值は, 10 分間放電電圧の変動を記録し，その平均値 をプロットした。

\section{3. 実 験 結果}

〈3.1〉 放電電圧に及ぼす放電回数の影響 図 $3(\mathrm{a})$, (b) は, 図 1 (a) に対応する基準電極の放電電圧の経時変 化を二つの試料で測定した結果を示し，図 3(c)，(d) は 図 1(b) に対応する誘電体付き電極の放電電圧の経時変化 を二つの試料で測定した結果を示す。それぞれ二つの試料 を用いたのは，再現性を確認するためである。図 $3(\mathrm{a})$, （b ）の基準電極の場合，最初の 10 秒は放電電圧が低めに 出て, その後は $12 \pm 2 \mathrm{kV}$ のレベルに安定している。この ように放電初期に放電電圧が低始るのは，電極に吸着 したガスや不純物の影響といわれ，従来からも知られた現 象である。

これに対し $(\mathrm{c}),(\mathrm{d})$ 図の誘電体付き電極の場合, 放電 電圧は最初加ら $5 \pm 1 \mathrm{kV}$ と低く, かつ安定している。放 電部から離れた位置に誘電体を配置するだけで放電電圧が $12 \mathrm{kV}$ から $5 \mathrm{kV}$ に下がるという現象は, 従来の知見では 想像できない特異な現象である。この原因を究明するのが 本研究の目的である。

誘電体を配置すると誘電体表面に電荷が蓄積され，その 電荷が次の放電に影響を及ぽすことも考えられる。そこ で，(c)，(d)図に示すように電荷が逃け゚るために十分な 時間 (24 時間) 実験を中断し再課電する実験も行った。 その結果, 再課電の 1 発目の放電電圧が高くなるという傾 向はなく, 最初から放電電圧は $5 \mathrm{kV}$ と低く安定してい た。

図 1 で示した電極構成の幾何学的配置からも, 誘電体の 誘電率あるいは誘電体表面の電荷が放電部電極の電界を大 幅に変えることは考えられないことである。

〈3・2〉放電電圧に及ぼすパルス頻度の影響 図 4 は 基準電極と誘電体付き電極を用いてパルス頻度を変え, 放 電電圧の変化を調べた結果である。放熱特性の悪い電極で は, パルス頻度が大きくなると放電部の電極温度が上昇し 熱電子を放出するため，放電電圧が低く安定することも考 えられる。しかし，実験した範囲では放電電圧がパルス頻 度によって変化することはなく, 熱的現象によって放電電 圧が低下したものではないことが確かめられた。

〈3・3〉放電電圧に及ぼすパルス波頭長の影響 は基準電極と誘電体付き電極についてパルス波頭長を変 え, 放電電圧の変化を調べた結果である。波頭長 $0.7 \mu \mathrm{s}$ と $4.9 \mu \mathrm{s}$ の実験では，インパルス発生装置を用い， $1.2 \times$ 


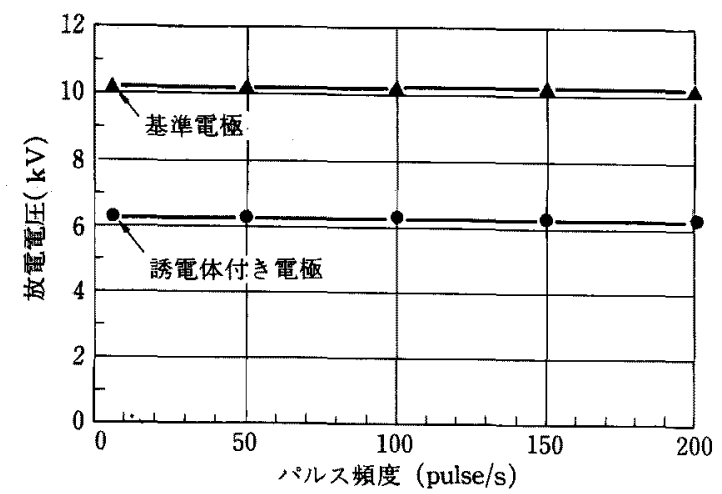

図 4 放電電圧に及ぼすパルス頻度の影響 Fig. 4. Effect of pulse repetition rate on discharge voltage.

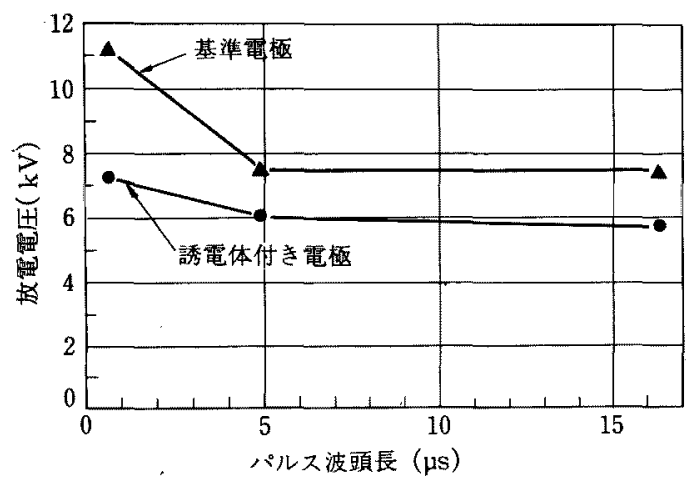

図 5 放電電圧に及ぽすパルス波頭長の影響 Fig. 5. Effect of pulse front length on discharge voltage.

$100 \mu \mathrm{s}$ と $10 \times 100 \mu \mathrm{s}$ の波形を作り, 放電電圧の 2 倍程度 の過電圧を印加し，放電時の電圧と放電までの時間をオシ ロスコープの画面から求めた。波頭長 $16.3 \mu \mathrm{s} の$ 実験で は, 図 2 で述べた高電圧回路を用い, 放電電圧の 2 倍程度 の過電圧を印加し, 放電時の電圧と放電までの時間を求め t。

図5のように，パルス波頭長が短い活ど放電電圧が高く なるのは, 従来から知られている現象である。これは放電 の統計時間遅れ, すなわち放電に必要な初期電子の存在確 率が時間が短いほど小さいためであると考えられている。 誘電体を配置することで放電電圧が低下したのは，放電の 時間遅れが小さくなったためとみることができる。パルス 波頭長の長い高電圧パルスでは, 誘電体がなくとも初期電 子が供給されるので, 誘電体配置の効果が低減している。

誘電体を付加することによって, 高電圧波形自体が変わ り立上りが遅くなれば，放電電压が低くなることが考えら れる。しかし, 実測した結果, 誘電体有無による波形の違 いは全く認められなかった。

\section{〈3・4〉放電電圧に及ぼす放電部-誘電体間距離の影響}

図 6 は, 図 1 (b)で示した放電部-誘電体間距離 $L$ と放 電電圧の関係を示す。誘電体が放電部から離れるほど放電 電圧が高くなり，30 $\mathrm{mm}$ 以上離れればほとんど効果がな

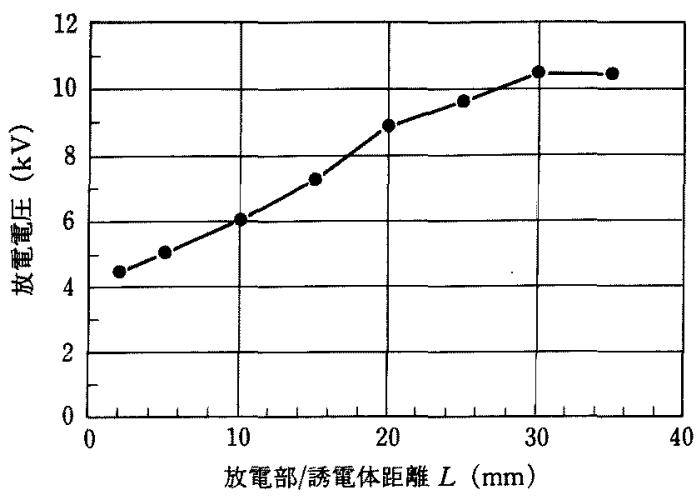

図 6 放電電圧に及济す放電部/誘電体間距離の 影響

Fig. 6. Effect of distance between discharge por tion and dielectric on discharge voltage.

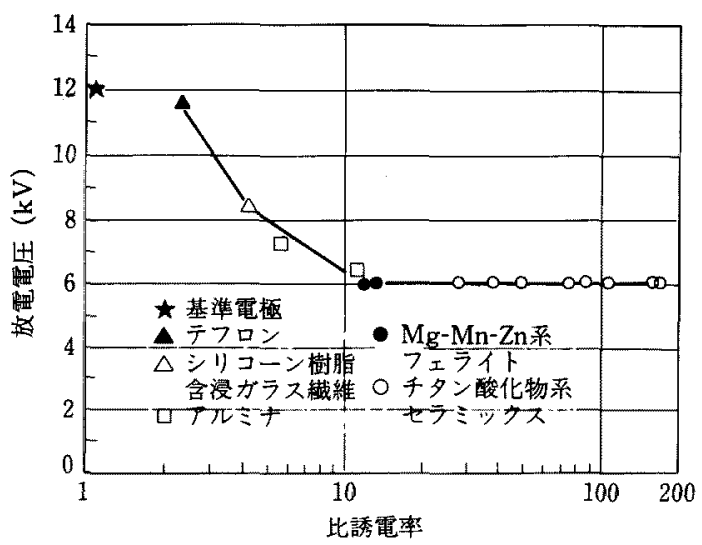

図 7 放電電生に及ぼす誘電体の比誘電率の影響

Fig. 7. Effect of specific permittivity of dielectric on discharge voltage.

くなっている。放電部の電極間ギャップは $1 \mathrm{~mm}$ である ので, 放電部から $10 \mathrm{~mm}$ や $20 \mathrm{~mm}$ 離れた位置に誘電体 を配置しても放電部の電界が大幅に変化するとは考えられ ない。これは，金属/誘電体間で予備電離が発生し，その 光によって主放電が起こると考えれば説明可能な現象であ る。

\section{〈3・5〉放電電圧に及ぼす誘電体の比誘電率の影響}

図 7 は, 表 1 に示した各種誘電体について放電電圧を測 定した結果である。ほほ同一の誘電率をもった材料はほほ 同じ放電電圧になる傾向が見られた。比誘電率が 10 以上 の材料を用いた場合に放電電圧が低かった。材料の体積抵 抗と放電電圧との関係も調べてみたが，体積抵抗率の高い テフロンやシリコーン樹脂含浸ガラス繊維の放電電圧は高 いものの,アルミナより体積抵抗率が高いチタン酸化物系 セラミックスの放電電圧がアルミナの放電電圧より低く, 材料の体積抵抗が高いほど放電電圧が高い傾向があるとは いえない結果であった。

金属と誘電体間の予備電離で発生した電荷は, 誘電体表 面に蓄積され，表面抵抗が高い場合には材料の体積抵抗と 静電容量で決まる時定数で減衰するものと考えられる。実 
験に用いた材料の時定数は表 1 の比誘電率と体積抵抗率か ら計算することができ，低体積抵抗率のフェライト以外の 材料はすべて1秒以上長い場合は数時間の時定数であるた め, 毎秒 50 パルスのパルス間隔 $20 \mathrm{~ms}$ の間に電荷は減衰 せずそのまま残留していると考えられる。従って, 残留電 荷がほとんど減衰しないほど十分高い体積抵抗率を有する 材料を用いたため, 体積抵抗率の値そのものの影響が出な かったものと思われる。

金属と誘電体との間の放電開始電圧は，1発目の放電に よる電荷が誘電体表面に残留するため，2 発目以降の放電 電圧に影響を与えることはよく知られている。本実験で は, 負極性高電圧パルスを毎秒 50 発の割合で連続して加 えているので, 負極性パルスの立上り時に予備電離が発生 すると，その電荷によりパルスの波尾の時点でギャップに 逆向きの高電界が加かり, 逆向きの予備電離が発生するも のと考えられる。すなわち，負極性のパルスだけを加えて も誘電体表面に残留する電荷によってギャップには正負の 電界が加わり，正負の予備電離が発生するようになる。金 属と誘電体間にある微小な空気ギャップでは, 誘電体の比 誘電率が大きいほどギャップに大きな電界が加わり予備電 離が発生しやすくなる。このギャップの予備電離によって 主ギャップの放電電圧が低下すると考劣れば，図 7 の結果 は説明できる。

もし，誘電体表面の抵抗が非常に低くなれば，空気ギャ ップに電圧がかからなくなり, 予備電離が発生せず主ギャ ップの放電電圧が高くなるという現象が起こるかもしれな い。しかし図 7 に示すように，化学的に安定で表面抵抗が 下がりにくい材料であるテフロンがもっとも放電電圧が高 くなっていることからみても，誘電体の表面抵抗が結果に 大きな影響を与えているとは考えられない。

〈3・6〉放電電圧に及ぼす金属/誘電体間ギャップの影響

これまでは，図1（b）に示すように金属と誘電体を接触 した状態で実験を行ってきた。図 8 は金属/誘電体間にギ ヤップを設け，特性の変化を調べた結果である。

ギャップ長さが大きくなると放電電圧が上昇する傾向 があり，ギャップの長さが $0.08 \mathrm{~mm}$ を超えると誘電体配 置の効果が見られなくなった。これは，ギャップの長さ $0.08 \mathrm{~mm}$ を超えると金属/誘電体間で予備電離が発生しな くなるためと考えられる。

〈3・7〉誘電体に加わる電位の影響 図 1(c)に示し たように，誘電体表面に導電塗料を塗り，導電塗料と金属 間を抵抗を介して接続し，放電電圧を測定した結果を図 9 に示す。抵抗無限大（接続せず）では，導電整料を溆らな い場合と同样放電電圧は低く，抵抗 0 (銅線で接続)で は, 誘電体を配置しない場合と同様放電電圧は高くなっ た。抵抗 $1 \mathrm{M} \Omega$ 程度が効果あり・なしの分岐点となってい る。抵抗值を小さくして誘電体と金属間に電位差が発生し ないようにす札，ここでの予備電離が起こらないため放 電電圧低隇効果がなくなるものと考元れば説明可能であ る。

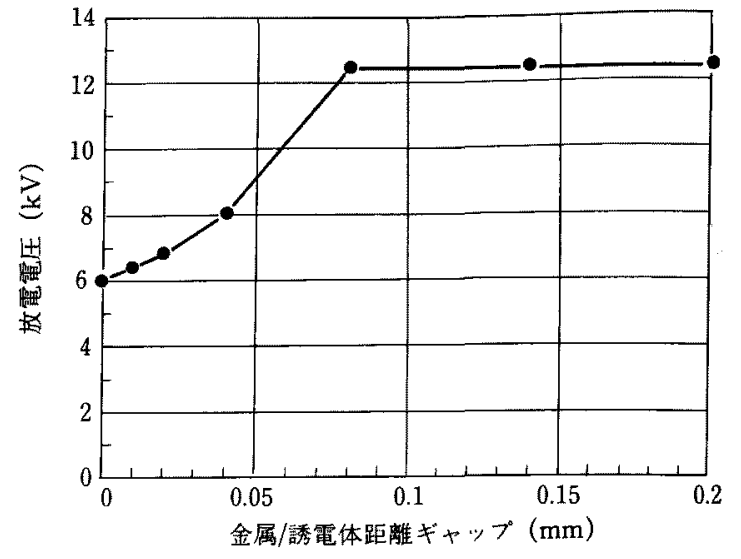

図 8 放電電圧に及ぼす金属/誘電体間 ギャップの長さの影響

Fig. 8. Effect of distance between electrode and dielectric on discharge voltage.

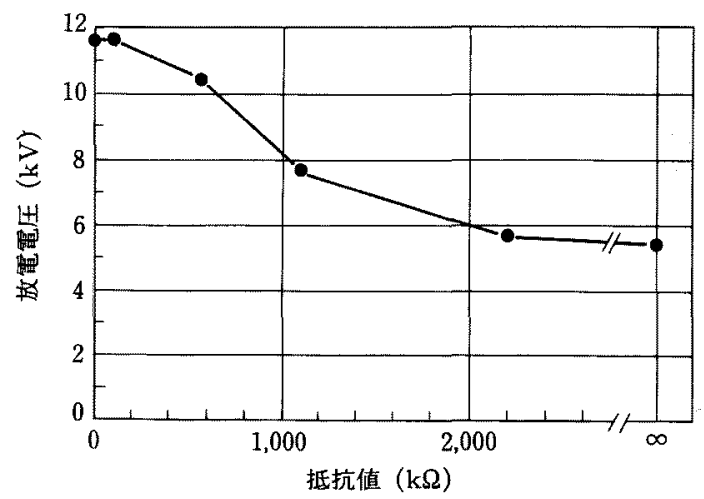

図 9 放電電圧に及ぽす誘電体/電極間抵抗值の 影響

Fig. 9. Effect of resistance between dielectric and electrode on discharge voltage.

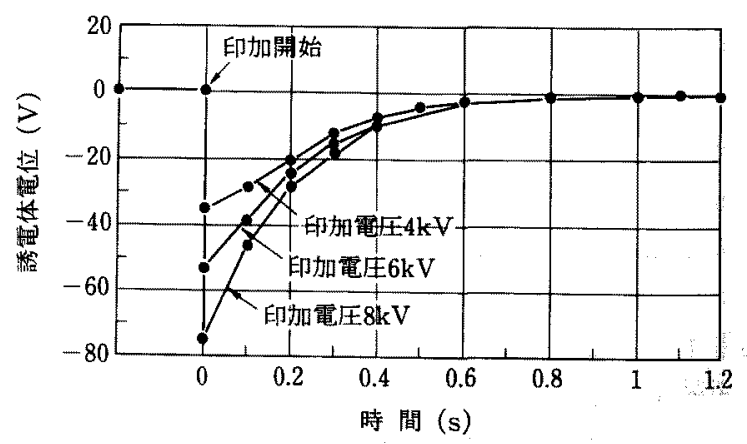

図 10 高電圧印加後の誘電体電位

Fig. 10. Potential of dielectric after high voltage application.

〈3・8〉 誘電体電位の測定 図1(d)で示した方法で チタン酸化物系セラミックスに高電圧パルスを加え，その 表面電位を測定した結果を図 10 に示す。誘電体電位の值 そのものは測定位置によっても変わり，それほど精度があ る值とはいえないが，電圧印加によって電位に変化が起こ る点が重要である。電位の減哀時定数は誘電体の種類によ 
って大幅に異なり，テフロンを用いて実験した場合は 30 分間でも電位の減衰は全く認められなかった。図 10 の結 果は誘電体にある電荷が消失する現象を表している。電圧 印加時に誘電体に電荷を与えているのは，電極端と誘電体 との接触部分での部分放電であると考えるのが妥当であ る。

〈3.9〉 放電部と誘電体間の遮光の影響 金属電極と 誘電体の界面で発生する予備電離による紫外線によって主 放電が発生しているならば，この両者の間に遮光板を入れ ることにより，放電電圧低減効果をなくすことができるは ずである。図 1 (d) に示したように遮光板を入れた結果, 図 11 に示すように放電電圧が上昇することが確認された。

\section{〈3・10〉 予備電離光の観察 これまでの実験結果は,} 金属電極と誘電体の間で発生する予備電離によって, 主放 電が始動するという仮説ですべて矛盾なく説明できる。そ こで，実験装置全体を暗室に入れ，主電極と対向電極間ギ ヤップを広げて主放電の発生を防ぎ, 真っ暗な状態で電極 端部での部分放電発生の有無を観察した。その結果, 高電 圧パルス印加時に電極端の誘電体との接触部で極めて微弱 な光が発生することを肉眼で観察でき，また，ASA 6000 の高感度フィルムを用い 5 分間シャッタを開いた状態で予 備電離光を撮影することができた。

図 12 はこの予備電離光と電極および主放電を重ねて撮

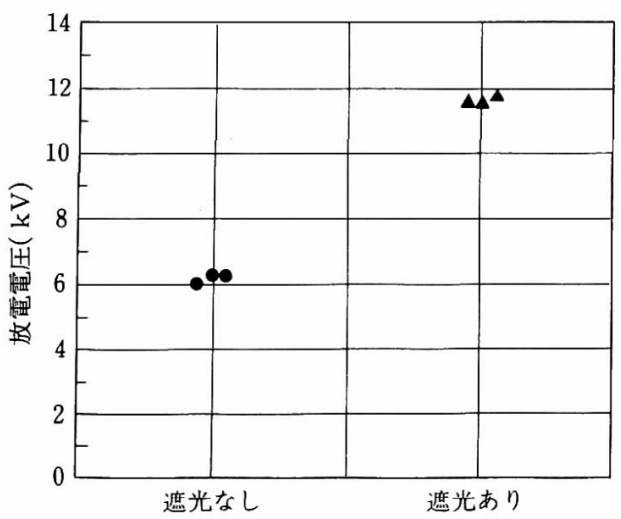

図 11 放電部/誘電体間遮光の影響

Fig. 11. Effect of light shield between discharge portion and dielectric.

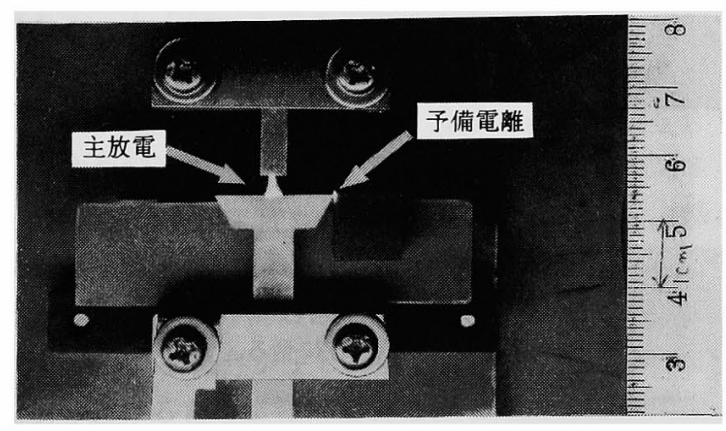

図 12 予備電離の発光

Fig. 12. Light emmittion of pre-ionization.
影した写真である。

\section{4. 考察}

以上の実験結果で，予備電離により主放電が始動してい ることは明らかになったが，ここではこの現象を簡単なモ デルを用いて数式化し概略計算を行い, 何が重要なパラメ ータであるかについて考察する。

電界が高くなる電極端部と誘電体の接触部は, 直線状と 考え, 中心線をもつ円筒状モデルで電界の近似計算を行 う。すなわち, 半径 $r_{1}$ の円筒状導体の外側に, 薄い空気 ギャップを介して円筒状 (外半径 $r_{2}$ ) の誘電体が配置さ れ，その外側に円筒状のアース (半径 $r_{3}$ ) があると仮定 する。電界を正確に求めるには, 電極の端部の $R$ や誘電 体の立方体形状，周囲のアース電位なども入力し，三次元 の計算を行う必要があるが, ここでは, 簡単のため解析解 が得られる円筒モデルで近似した。

電極端部の薄い空気ギャップの電界 $E$ は, 次式で与え られる。

$$
\begin{aligned}
& E=\frac{V}{r_{1}} \frac{1}{1 / \varepsilon_{s} \cdot \ln \left(r_{2} / r_{1}\right)+\ln \left(r_{3} / r_{2}\right)} \cdots \cdots \cdots \cdots \cdots \\
& \text { ここに, } V: \text { 電压, } \varepsilon_{s}: \text { 誘電体の比誘電率 }
\end{aligned}
$$

実験に用いた電極は，厚み $1.5 \mathrm{~mm}$ の板を切り抜いた ものであるため，角を完全にとれば $r_{1}$ は最大 $0.75 \mathrm{~mm}$ と なるが，角落としを行っていないので，実際には平な先端 の角に $0.03 \mathrm{~mm}$ 程度の $R$ が付いた形状になっている。こ こでは，等価的な $R$ を $0.2 \mathrm{~mm}\left(r_{1}=0.2 \mathrm{~mm}\right)$ ととった 場合を基準条件として， $R$ を変えた場合の電界も計算し てみた。実験状況を考えると， $r_{2}=10.2 \mathrm{~mm}$ (誘電体は 10 $\mathrm{mm}$ 角)， $r_{3}=100.2 \mathrm{~mm}$ (電極端とアース間距離は 100 $\mathrm{mm}$ 程度）を基準条件にとるのが妥当である。

(1)式の分母は，平等電界に換算した等価的なギャップ の長さである。比誘電率 $\varepsilon_{s}$ と等価ギャップ長の関係を (1)式の分母を用いて計算した結果を図 13 に示す。

この図で，等価ギャップ長 $1 \mathrm{~mm}$ を上限としているの は，主放電部のギャップの長さが $1 \mathrm{~mm}$ であるため，予 備放電による主放電の始動が起きない領域と考えたためで

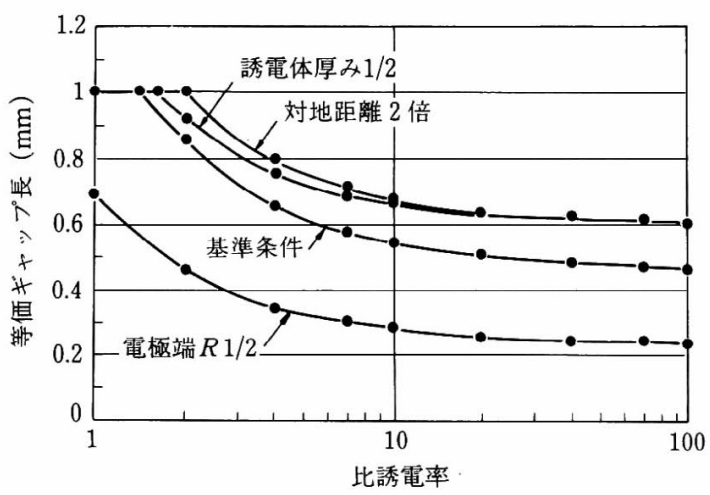

図 13 比誘電率と等価ギャップ長との関係 Fig. 13. Relation between specific permittivity and equivalent gap length (calculated). 
ある。等価ギャップ長が小さいほど, 低い電圧で部分放電 が発生すると考えられ，この部分放電によって主放電が始 動すると考えれば, 図 7 の実測值は, 図 13 の計算値と対 比することができる。

図 13 の基準条件の計算値と図 7 の実測值がよく合致す るのは, $r_{1} と し て ~ 0.2 \mathrm{~mm}$ を選んだことにもよるが, 比 誘電率が 1 から 10 程度変化する間に放電電圧が大幅に下 がるという傾向は，(1)式を導いた基本的な考え方，すな わち電極端に誘電体を配置することによって電極端の電界 が高くなり，予備電離が発生するという説が正しいことを 裏付けるものである。

図 13 には，基準条件に比べ電極端 $R$ を $1 / 2$ 倍にした場 合, 誘電体厚みを $1 / 2$ にした場合, 対地間距離を 2 倍にし た場合の計算結果も併記した。電極端 $R$ を小さくすれば, 誘電体を配置しなくとも部分放電が発生する可能性がある が，この場合にも誘電体を配置すればほぼ同じ倍率の放電 電圧低減効果が期待されることがわかる。誘電体の厚みを 薄くすれば放電電圧低減効果も小さくなる傾向がある。対 地距離を 2 倍 $(100 \sim 200 \mathrm{~mm})$ に変える効果は, 誘電体 厚みを $1 / 2$ 倍（10 $5 \mathrm{~mm})$ に変える効果と同程度であっ た。

同筒モデルは，概略計算のために用いているもので，計 算結果の数値そのものの精度には疑問があるが, 何が重要 なパラメータであるかを明らかにするためには有効な手段 である。上記の結果は, 予備電離発生場所に近い電極端の $R$ の影響が最も大きく, 次に誘電体厚みの影響が大きく, 離れた位置にある対地距離の影響は比較的小さいことを意 味しており,この結果は, 円筒モデルの代わりに同心球モ デルを用い, 電極端を適当な球に置き換えて計算しても, 同じ結論を導出することができる。ここでは，このモデル の基礎となっている考え方, すなわち電極端に誘電体を配 置することによって電極端の電界が高くなることを円筒モ デルを例にとって説明しているのである。このモデル化に よって, 誘電体の比誘電率が 1 から 10 に変化すると放電 電圧が大幅に変わるという図 7 の実験事実をより鮮明に説 明できるだけでなく，本論文で実験検証されていない電極 端 $R$, 誘電体厚みあるいは対地距離などのパラメー夕の 重要性についても指摘することができた。本論文で明らか にした現象を実際に応用するには，これらの寸法関係をよ り定量的に解明する必要があり,ここで提起したモデルの 考え方が役立つことを期待するものである。

\section{5. 結言}

自動車点火系ディストリビュータ用電極で, 放電部から 離れた電極端に誘電体を配置することにより, 放電電圧が 大幅に低下し安定化する特異現象を発見し, その原因究明 を行った。

その結果, 電極端と誘電体の間で予備電離が発生し, そ れが主放電を始動させる現象であることが明らかとなっ た。
この電極は, 始動用回路や始動用の第 3 電極なしに一つ の高電圧パルスを加えるだけで, 予備電離により自己始動 する機能を有している。

この電極は, 放電電圧が低く安定するだけでなく, 主放 電による予備電離部の損傷がないため, 原理的に耐久性が 高く，低雑音ディストリビュータ用電極として実用化され ることが期待される。

(平成 7 年 4 月 10 日受付, 同 7 年 8 月 25 日再受付)

$$
\text { 文献 }
$$

(1) R. A. Shepherd, et al.: "New Techniques for Suppression of Automotive Ignition Noise", IEEE Trans. Vehicular Technology, 25, No. 1 (1985)

（2）堤・小野・藤井・長江・粕谷：「セラミック抵抗体放電電極の電 波雑音抑制効果」, 電学論 $\mathrm{A}, 110,153$ (平 2-2)

（3）堤・小野・藤井・檜垣・石井：「微小ギャップ放電からの電波雑 音の抑制」, 同上 $B, 110,850$ (平 $2-10$ )

（4）渡部：エキシマレーザの開発とその応用技術・例（昭 62）応用技 術出版

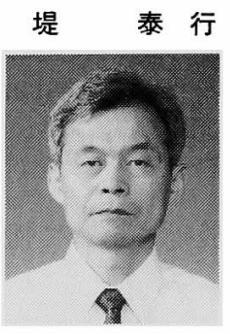

（正員） 1938 年 1 月 18 日生。1960 年 3 月九州 大学工学部電気工学科卒業。同年 4 月(株)日立 製作所日立研究所入社。以来, 電力機器の絶縁 研究および燃料電池の開発に従事。1989 年 3 月 退社。同年 4 月茨城大学工業短期大学部, 1990 年 10 月同工学部システム工学科教授となり, 現 在に至る。工学博士。電気化学協会会員。

沼田義道（正員） 1945 年 2 月 13 日生。1963 年 3 月水戸

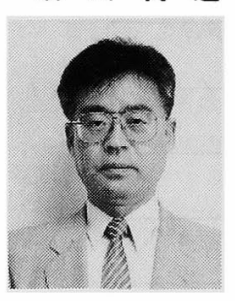
工業高等学校採鉱冶金科卒業。同年 4 月(株) 日 立製作所日立研究所入社, 現在に至る。

長 江 弘允 (非会員) 1943 年 1 月 6 日生。1961 年 3 月徳島

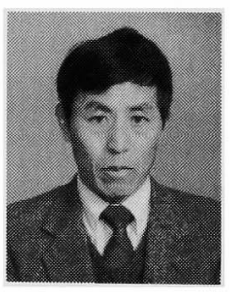
工業高等学校機械科卒業。同年 4 月 (株) 日立製 作所入社, 現在に至る。電子情報通信学会会員。

弓野真 孝 (非会員) 1960 年 2 月 22 日生。1 1978 年 3 月茨

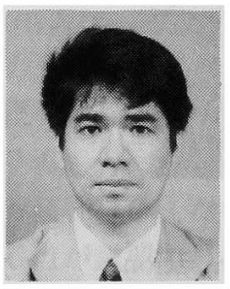
城県立高萩高等学校普通科卒業。同年佐和産業 入社。日立オートモーティブエンジニアリング (株)を経て，現在に至る。 